\title{
Comparison of the Effect of Lecture Training and Clinical Education on the Care of Patients with Angina Pectoris on Attitude of Nurses in Emergency Department of Military Hospitals of in Mashhad
}

\author{
Yousefi. $\mathrm{R}^{1}$ \\ Farsi. Z 2* \\ Rajai. $N^{3}$ \\ 1- MSC in Student of Emergency \\ Nursing, Student Research \\ Committee, Faculty of Nursing, \\ Aja University of Medical \\ Sciences, Tehran, Iran. \\ 2- ( ${ }^{\star}$ Corresponding Author) \\ Ph.D. in Nursing, Associate \\ Professor, Research \\ and Community Health \\ Department, Faculty of \\ Nursing, Aja University of \\ Medical Sciences, Tehran, \\ Iran. \\ Email: z.farsi@ajaums.ac.ir; \\ zahrafarsi@gmail.com \\ 3- MSc in Nursing, Maternal \\ and Newborn Department, \\ Instructor, Faculty of Nursing, \\ Aja University of Medical \\ Sciences, Tehran, Iran.
}

\begin{abstract}
Introduction: Nursing education has the task of preparing graduates with the ability to identify the needs of patients in a changing society and in the clinical setting, and provide the best possible care based on the best scientific evidence.

Objective: The aim of this study was to compare the effect of lecture and clinical education on the care of patients with angina pectoris on attitude of nurses in the emergency department of military hospitals in Mashhad.

Material and Methods: This single-blind randomized clinical trial was performed on 58 nurses in Emergency Department of Military Hospitals in Mashhad, Iran in 2018-2019. Nurses were divided into three groups: lecture training, clinical education and control groups. The data gathering tool was a researcher-made attitude questionnaire that was completed before, immediately and one month after intervention in all three groups, and the level of attitude of care for angina patients in each group was determined and compared. Data were analyzed by SPSS software version 22 using statistical tests.
\end{abstract}

Results: The Kruskal Wallis and the Median Test showed that the three groups had no significant difference in attitude scores before intervention $(\mathrm{P}=0.821)$ and $(\mathrm{P}=0.456)$, respectively. One-way ANOVA showed that the attitude of the three groups was significantly different immediately after intervention $(\mathrm{P}<0.001)$ and one month after the intervention $(\mathrm{P}<0.001)$. The mean score of the clinical group was higher than the other two groups, and the post hoc test showed that the attitude of each group was significantly different $(\mathrm{P}<0.001)$.

Discussion and Conclusion: The results of this study showed that training by lecture method and clinical education increased attitude of nurses in the care of patients with angina pectoris, but the effectiveness and durability of these trainings was higher in clinical education method. Also, in this study, clinical education was more effective than lecture training, and increasing attitude of nurses in clinical education was more stable. Therefore, it is suggested that more effective methods be used to educate nurses such as clinical education and similar methods.

Keywords: Education, Clinical Education, Angina Pectoris, Nurse, Lecture, Attitude

IRCT No.: IRCT20181015041350N1 


\title{
مقايسه تأثير آموزش به روش سخنرانى و آموزش بالينى نحوه مر اقبت از بيماران مبتلا به

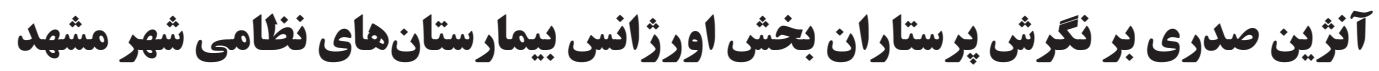

\author{
رضا يوسفى'، "زنهر افارسى'، ناهيد رجايى"
}

مقدمه: آموزش يرستارى وظيفه آمادهسازى دانشآموختكان با كفايتى را بر عهده دارد كه بتوانند در محيط در حال تغيير

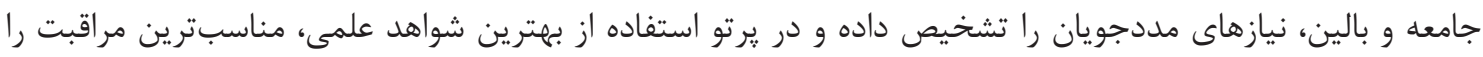

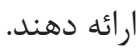
هدف: اين يزوهش با هدف مقايسه تأثير آموزش به روش سخنرانى و آموزش بالينى نحوه مراقبت از بيمار ان مبتلا به آنزين

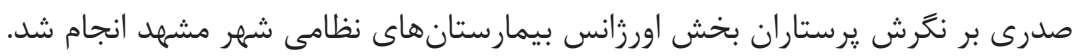

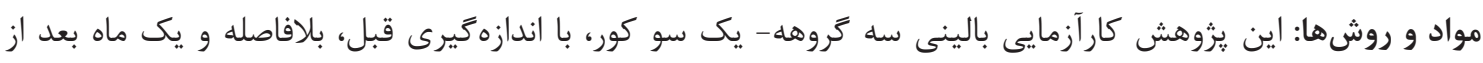

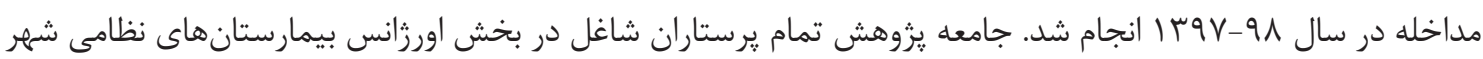

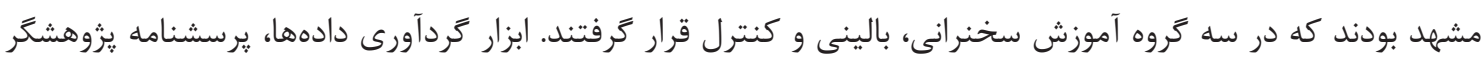

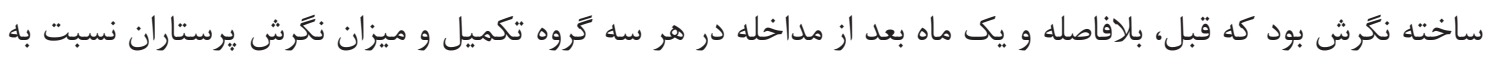

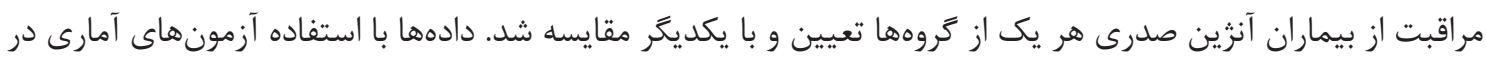

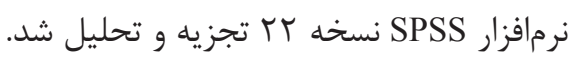

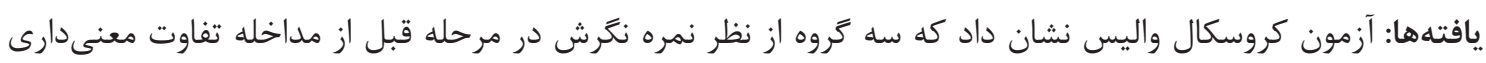

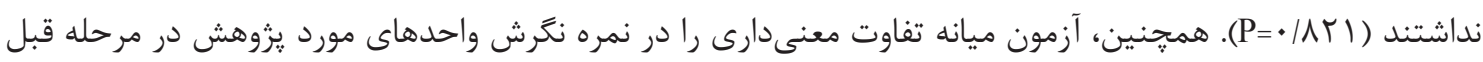

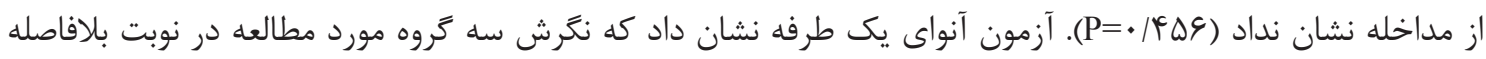

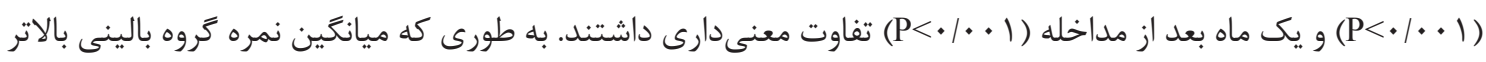

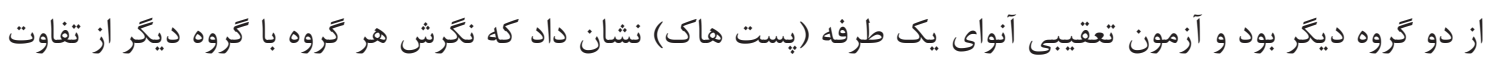

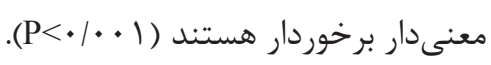

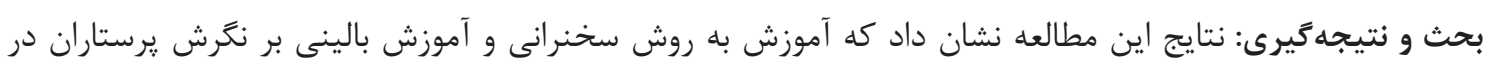

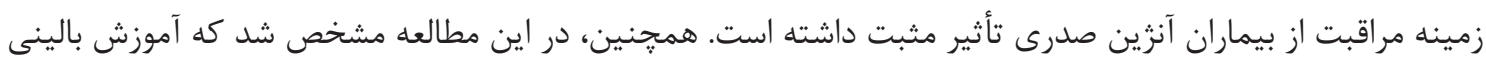

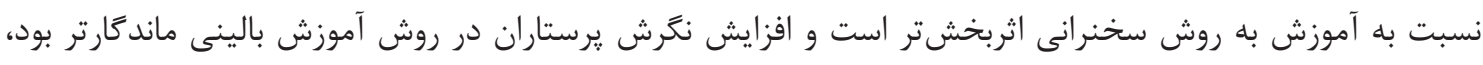

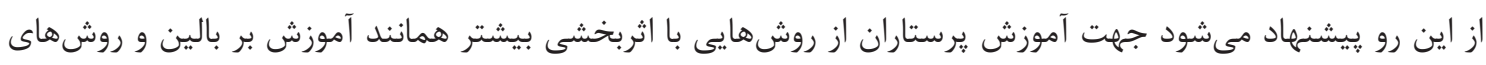
مشابه استفاده كردد.

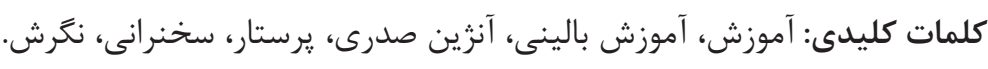

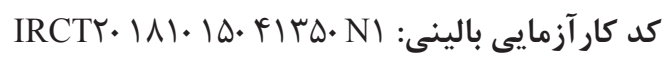

\begin{tabular}{|c|c|}
\hline 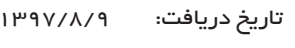 & 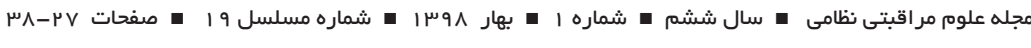 \\
\hline 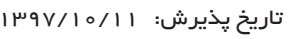 & \\
\hline 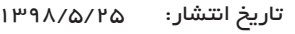 & \\
\hline
\end{tabular}

از بيمارى مىباشند (1). در ميان بيمارىهاى ايسكميك قلبى،

مقلمه

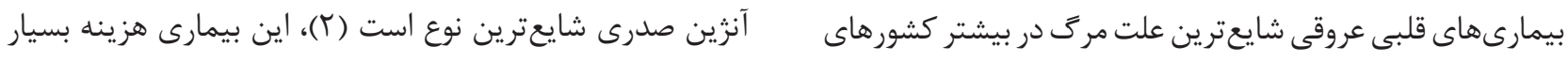

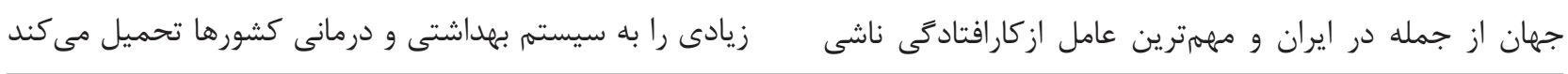

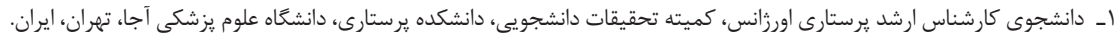

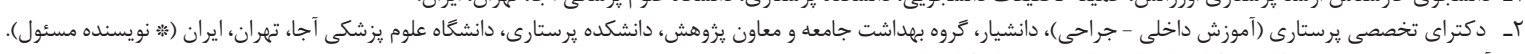

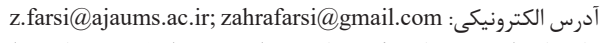


است تا اين آموزش به مؤثرترين شيوه ممكن براى ڤيرستاران

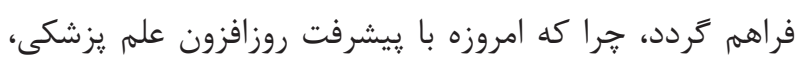

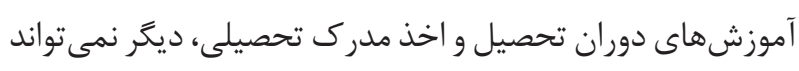

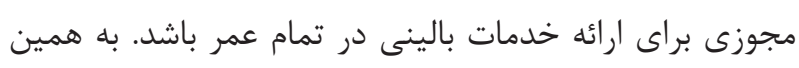

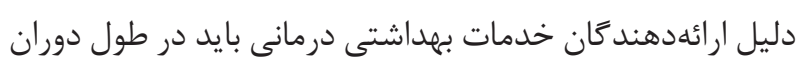

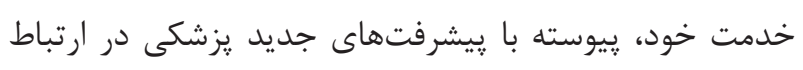

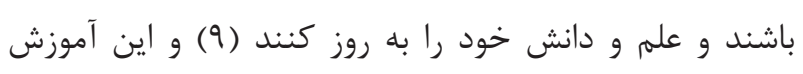
بايد بر اساس آخرين يافتههاى دانش و استانداردها باشد (• (1).

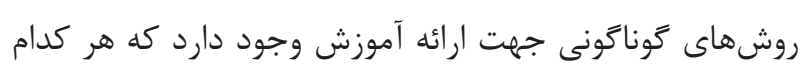

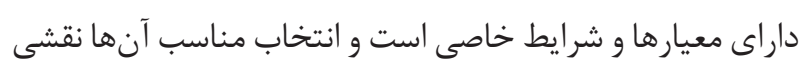

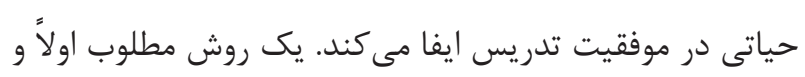

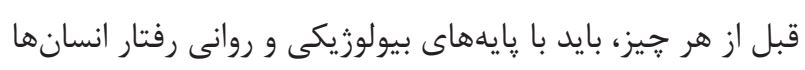

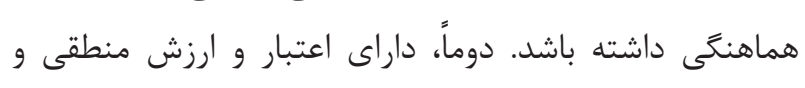
همسو و همجهت با روشهاى معتبر كسب دانش باشد، سوماً،

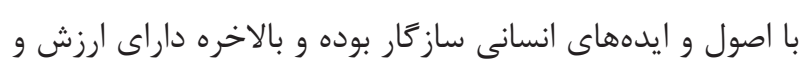

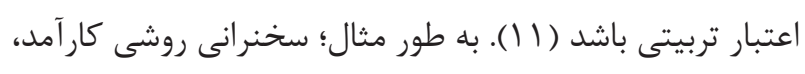

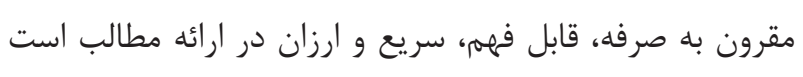

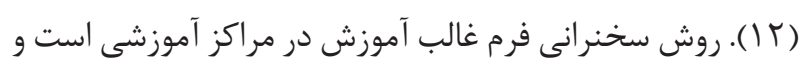

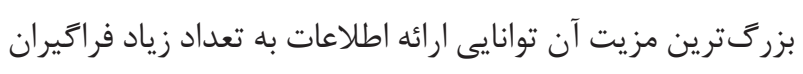

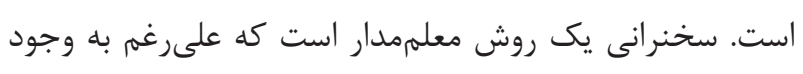

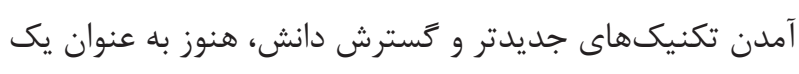
روش آموزشى مههم تلقى مى

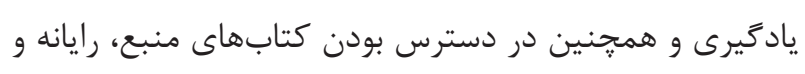

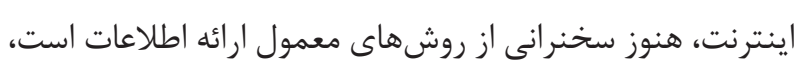

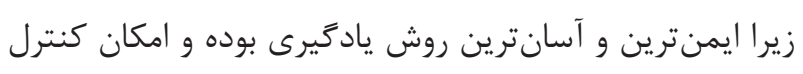

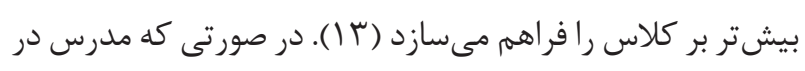

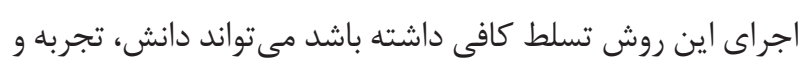

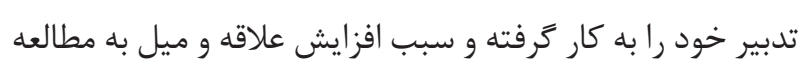

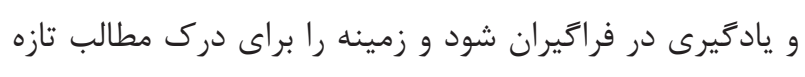

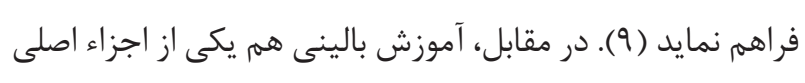

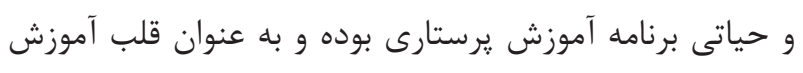

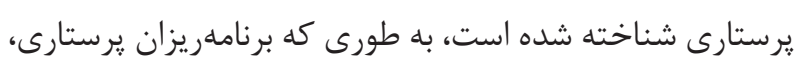

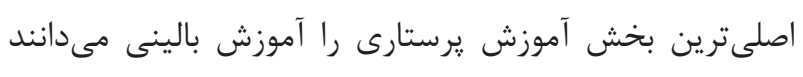

و با اين وجود، شواهد نشان داده است كه اين بيمارى يكى از قابل ييشخيرىترين بيمارىهاى غير واگير به شمار مى آيد (؟). اين بيمارى با عدم تحمل فعاليت بر كيفيت زندكَى بيماران تأثير

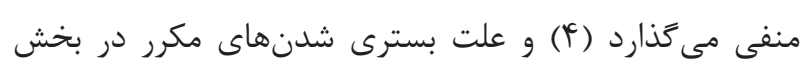

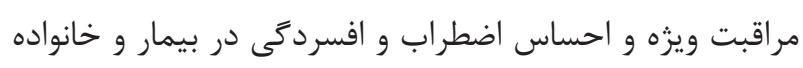
او محسوب مىشود. لذا، براى كنترل بهتر بيمارى و برخوردارى

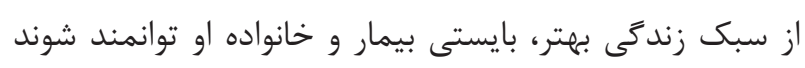

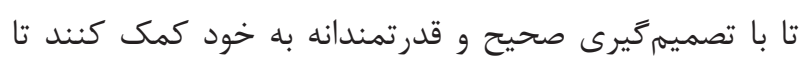

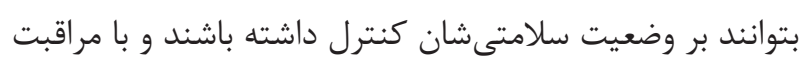

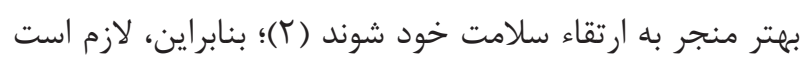

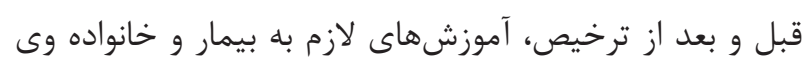

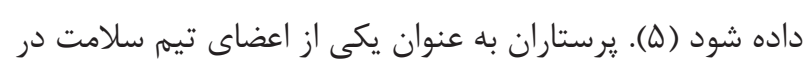

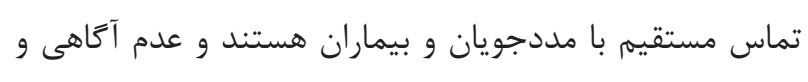

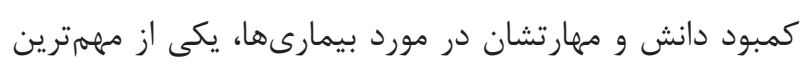

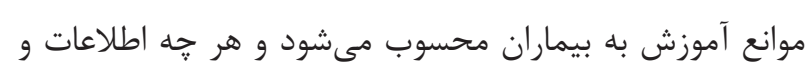
دانش يرستاران كمتر باشد به همان نسبت آموزش به به بيماران

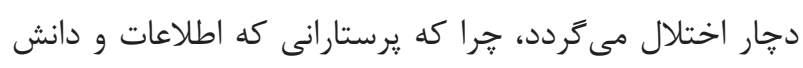

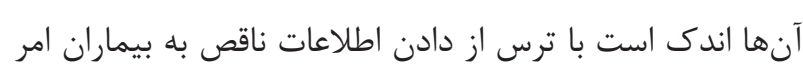

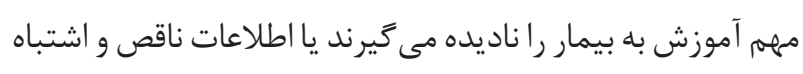

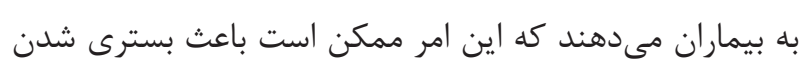

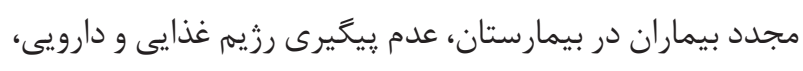

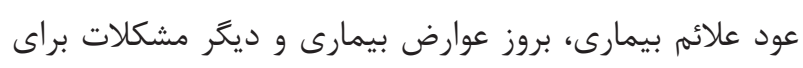

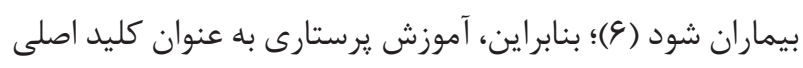

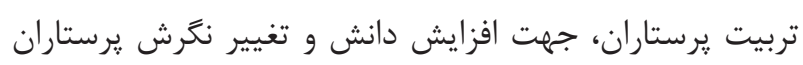

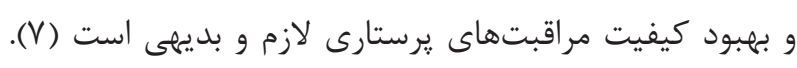

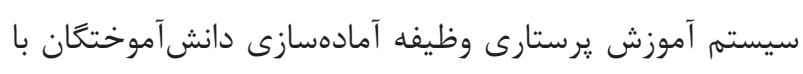
كفايتى را بر عهده دارد كه بتوانند در محيط در حال تغيير

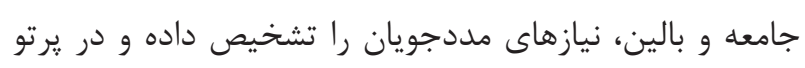

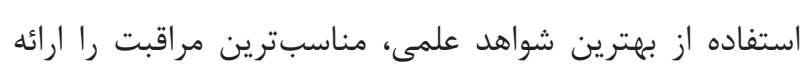

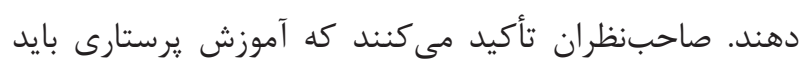
ضمن كنجاندن روشهاى نوين آموزشى در برنامههاى خون،

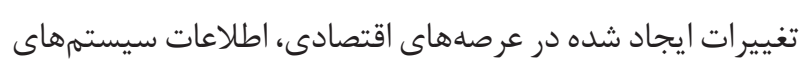

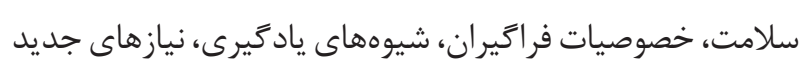

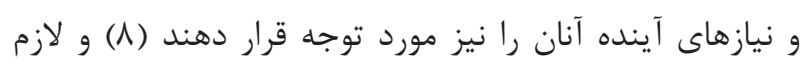


تأثير آموزش به روش سخنرانى و آموزش بالينى نحوه مراقبت از

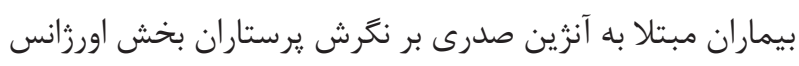
بيمارستان هاى نظامى شهر مشهد انجام شد.

\section{مواد و روشها}

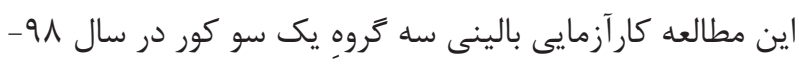

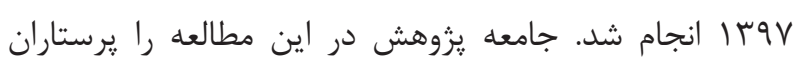
شاغل در بخشهاى اورزانس بيمارستانهاى نظامى شهر مشهد

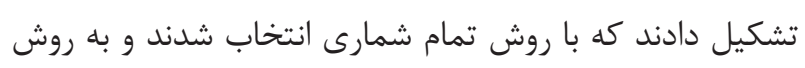
تصادفى ساده در ب گروه آموزش به روش سخنرانى (بيمارستان الف)، آموزش بالينى (بيمارستان ب) و كنترل (بيمارستان ج) قرار

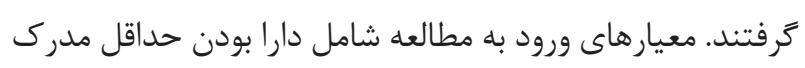

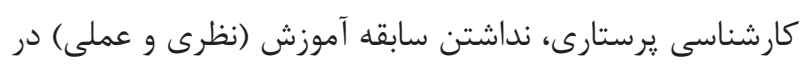

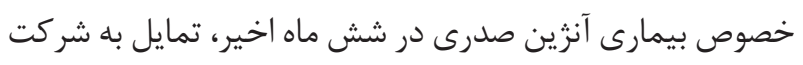

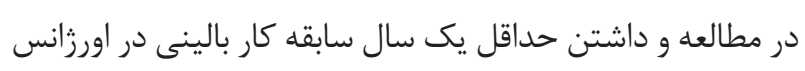

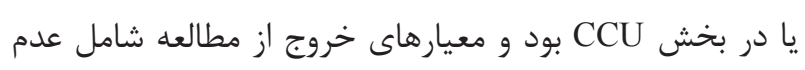

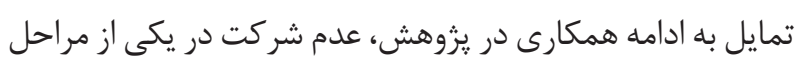

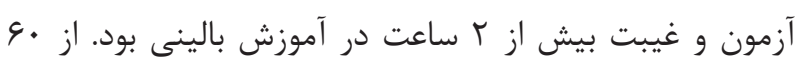

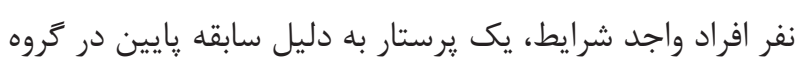

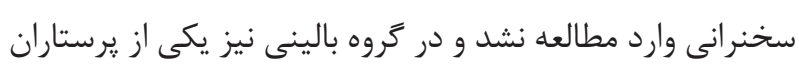

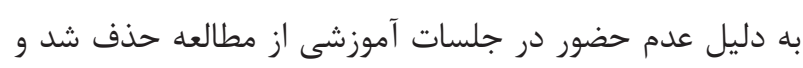
در كل ه ه يرستار مورد مطالعه قرار كرفتند.

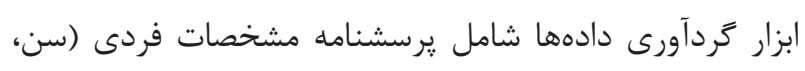
جنس، وضعيت تأهل، سطح تحصيلات، مدت سابقه كار بالينى،

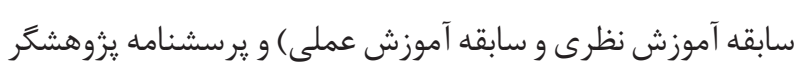
ساخته نكرش بود. يرسشنامه نكرش داراى V سؤال با گز ينههاى

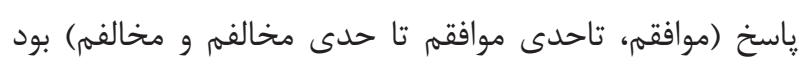

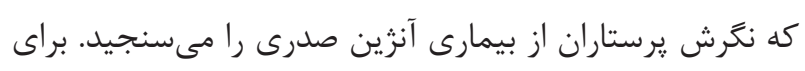

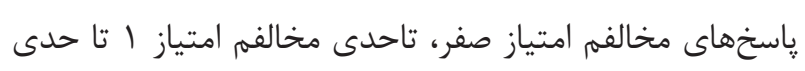

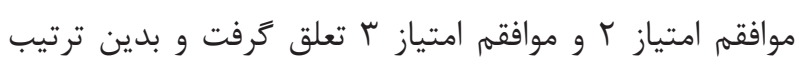

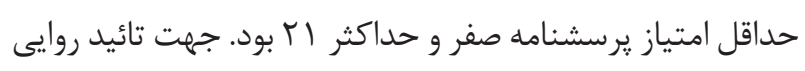

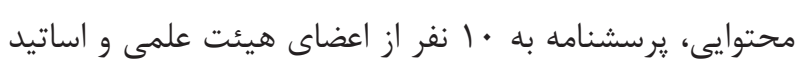

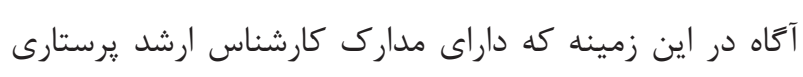

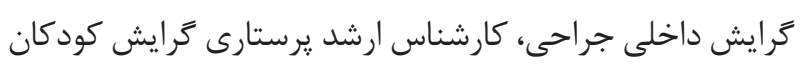

بالينى يكيار خكَى به وجود مى آورد. محيط بالينى موقعيتى براى

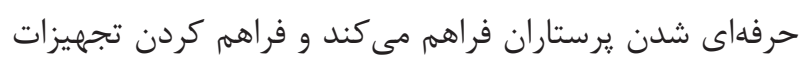

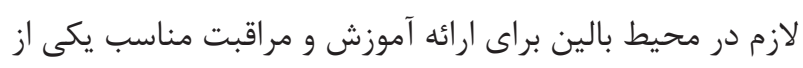
موارد مهمى است كه نبايد توسط مسئولين ناديده گرفته شود،

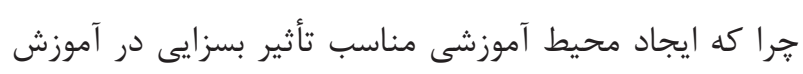

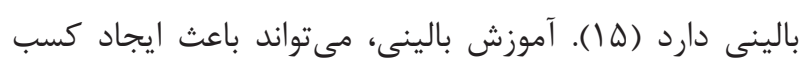

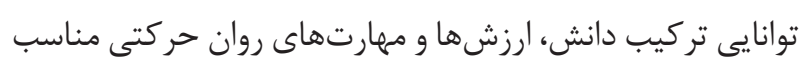

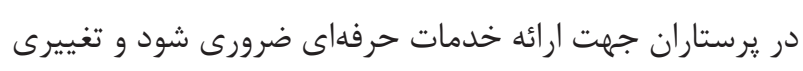

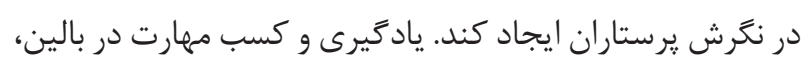

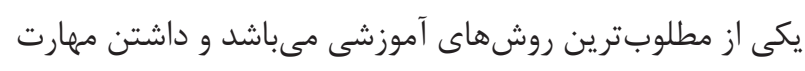
بالينى، به يرستاران حس كفايت مى دهد كه اين احساس كفايت،

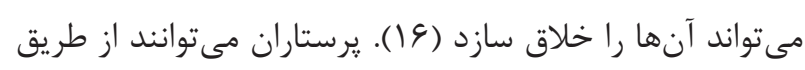

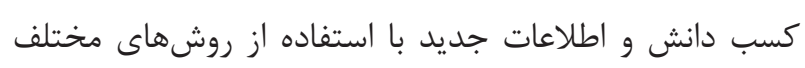
آموزشى، تغييراتى در جزء شناختى نكَرش خود به وجود آورند

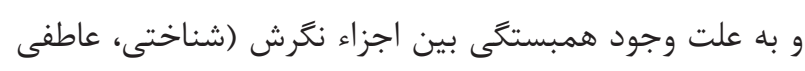

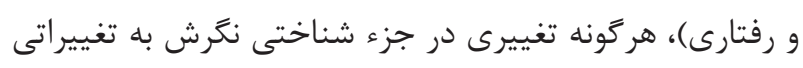

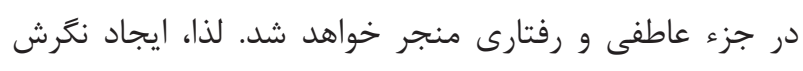

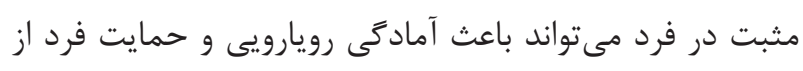

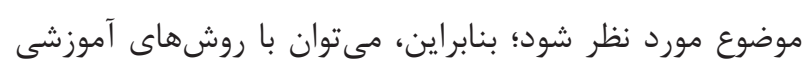

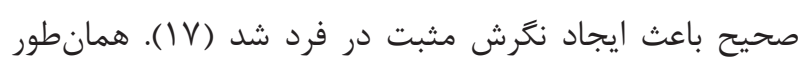

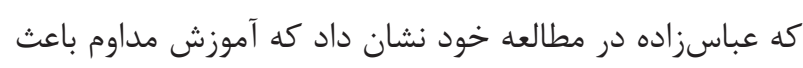

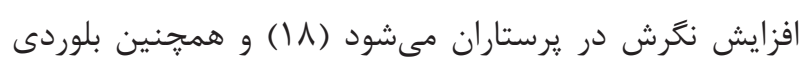

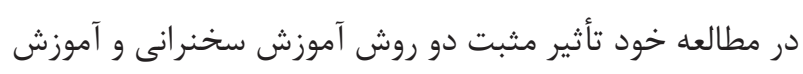
بالينى را بر دانش و نحَرش يرستاران نشان داد (9 (1).

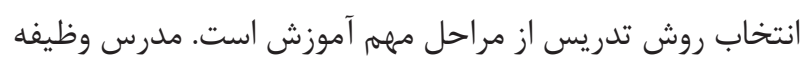

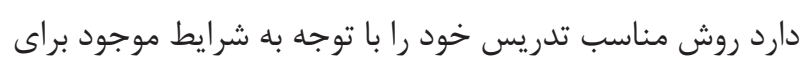

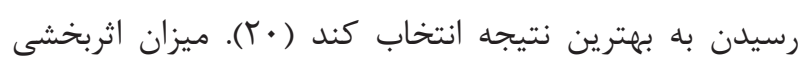

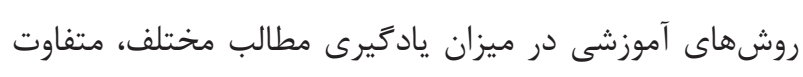

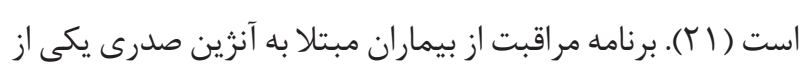

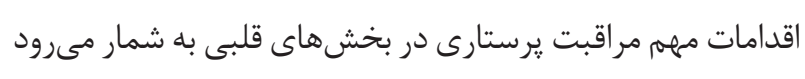

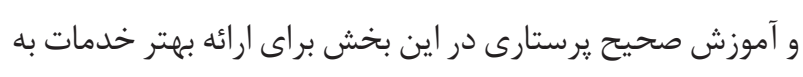

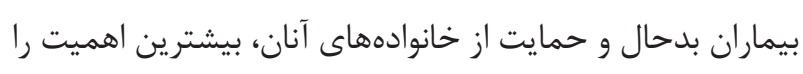

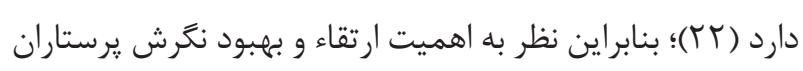

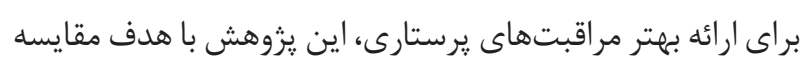


. 1 نفره در شيفت صبح يك روز و يك گروه 9 نفره در شيفت صبح يك روز ديخر در جلسات آموزشى شركت نمودند. در انتهاى دوز

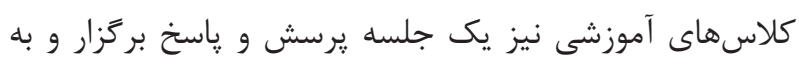
سؤالات يرستاران ياسخ داده شد.

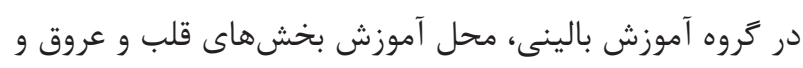

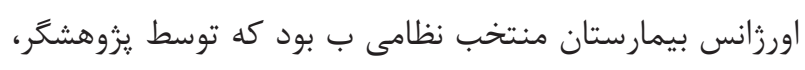

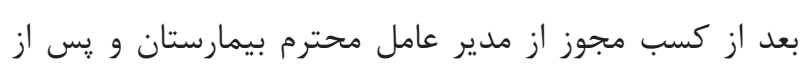

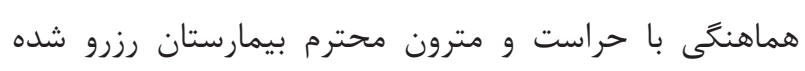

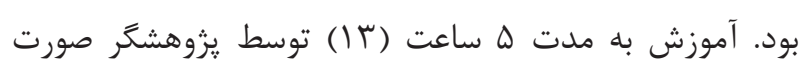

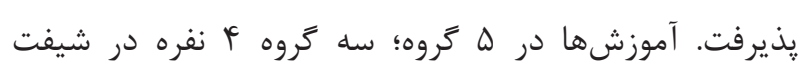

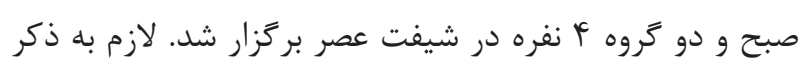

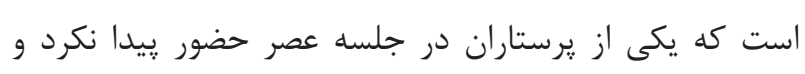

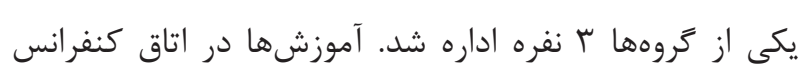

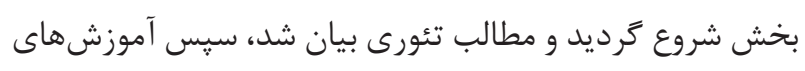

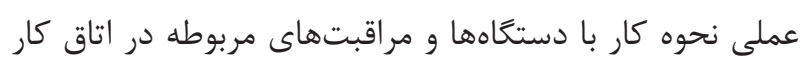

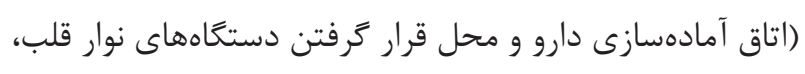

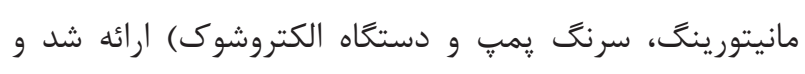
آموزشهايى همانند جَّونگى كَرفتن شرح حال، علائم بيمارى،

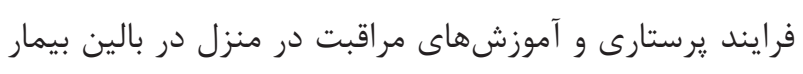

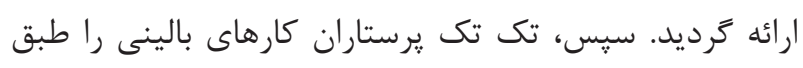

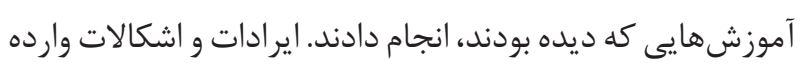

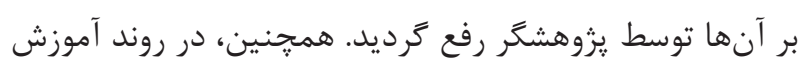

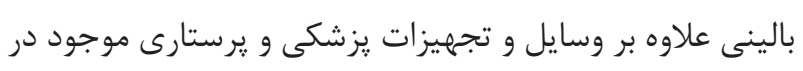

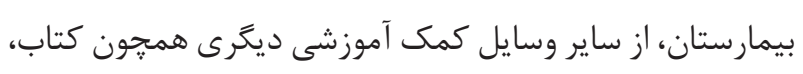

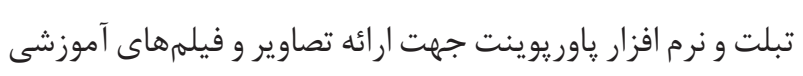

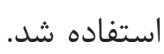

لازم به ذكر است كه در اين مطالعه محتواى آموزش بيمارى آنزين صدرى طبق طرح درس از قبل تهيه شده توسط تيم يزوهش و بر اساس آخرين نسخه كتاب يرستارى داخلى -جراحى برونر و و

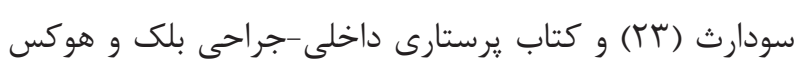
ئ (YY) يمب: و الكتروشوك (مختص هر دستخاه در بخش مربوطه) توسط
و دكتراى يرستارى از دانشخاه علوم يزشكى سبزوار، دانشكاه

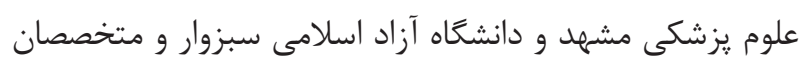

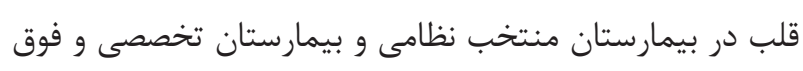
تخصصى حشمتيه سبزوار جهت بررسى مناسب بودن محتوا، قابل

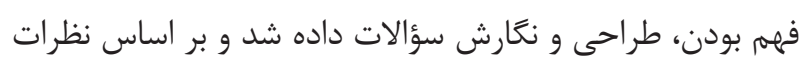

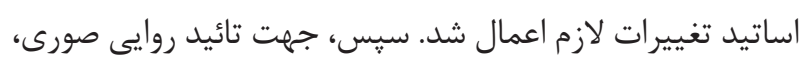

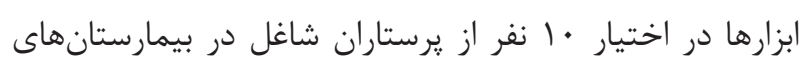

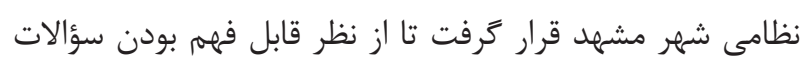
مورد بررسى قرار كيرد و تغييرات لازم در اين حوزه نيز اعمال شد. جهت بررسى يايايى يرسشنامه نكرش از روش آزمون - آزمون

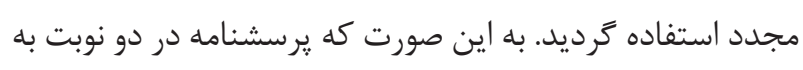

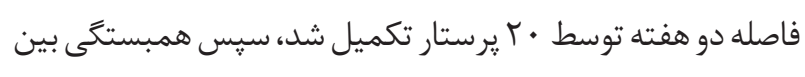

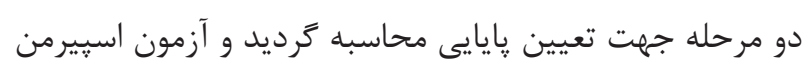

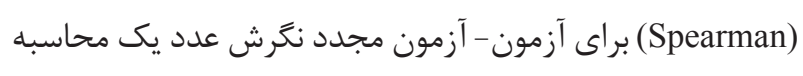

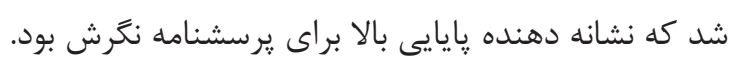

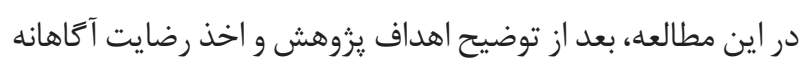

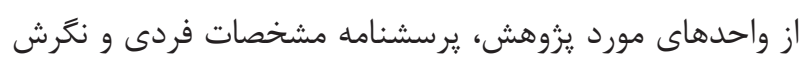

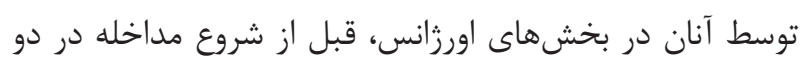
كروه آزمون (آموزش به روش سخنرانى و آموزش بالينى) و كروه كنترل تكميل كرديد (ييشآزمون).

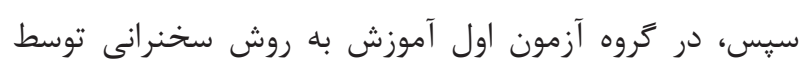

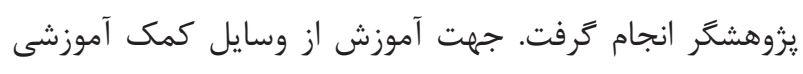

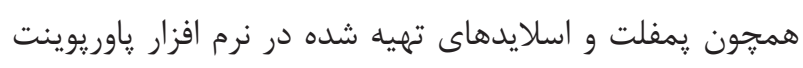

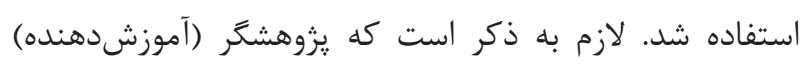

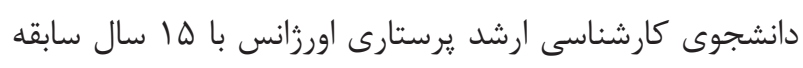

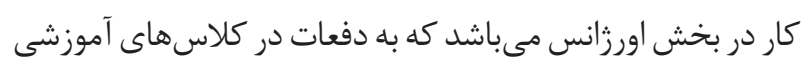
بيمارىهاى قلبى به عنوان مدرس مشاركت داشته است. با اين

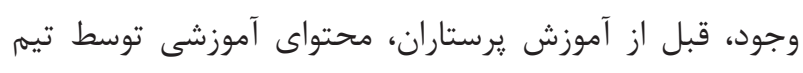

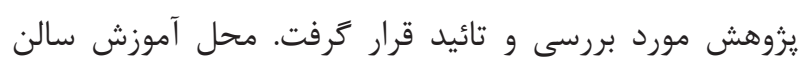

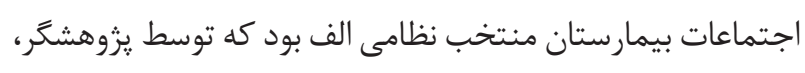

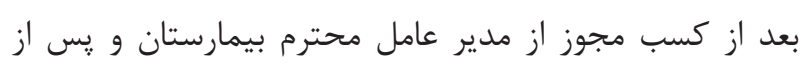
هماهنكى با حراست و مترون محترم بيمارستان رزرو شده بود.

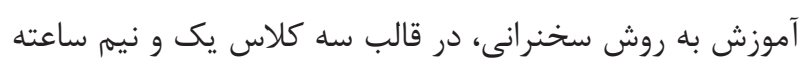

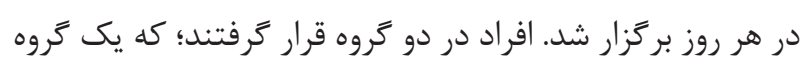


قلبى بود. اعتبار محتواى آموزش توسط اعضاى هيئت علمى

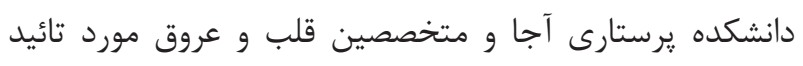

$$
\text { قرار گرفت. }
$$

سيس، يرسشنامه نكرش بلافاصله و يك ماه بعد از اتمام جلسات آموزشى در دو كروه آزمون توسط يرستار ان تكميل شد (يس بـ بآزمون).

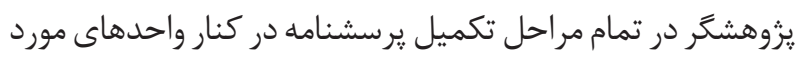

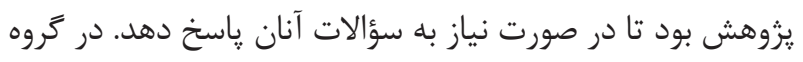

بروز بيمارى و انواع آن، علائم بالينى بيمارى، راههاى تشخيصى

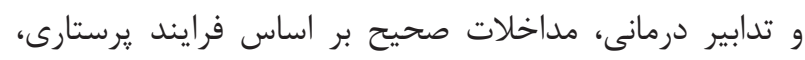

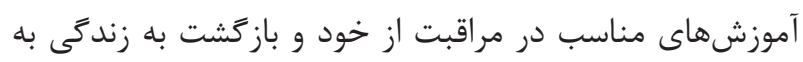
بيمار و خانواده او، نحوه صحيح كرفتن نوار قلب، نحوه صحيح

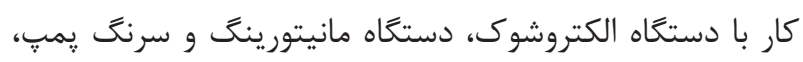
تفسير صحيح امواج در دستگاه مانيتورينگ بالاى سر بيمار، نحوه

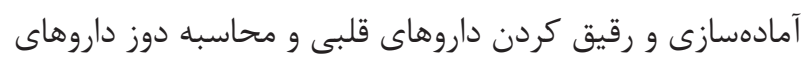

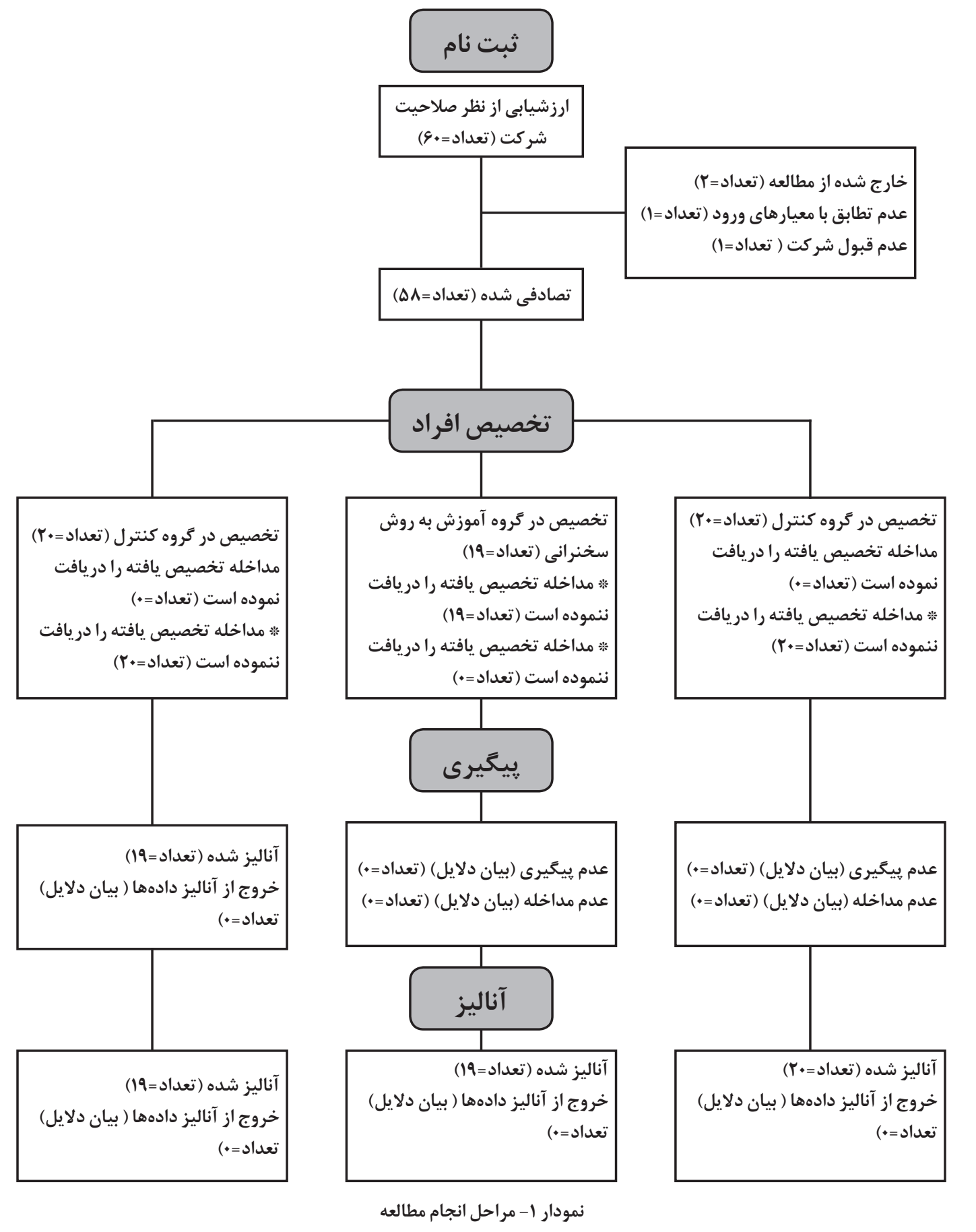


مطالعه طبق اصول كميته بين المللى اخلاق نشر Committee) of Publication Ethics)

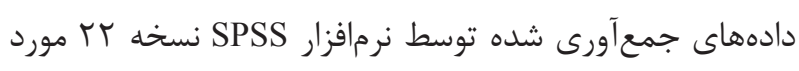

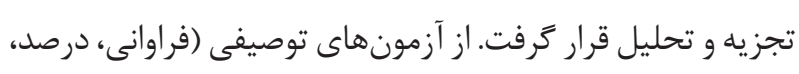

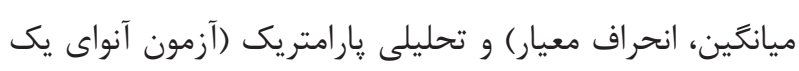

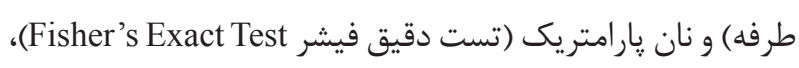

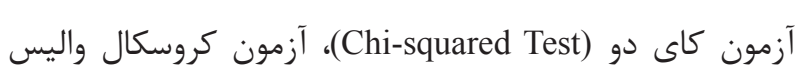

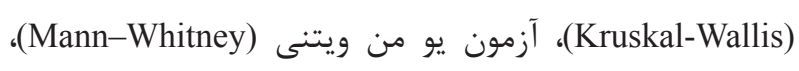

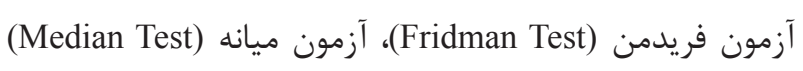
و ضريب همبستكى اسييرمن (Spearman) جهت تحليل دادهها

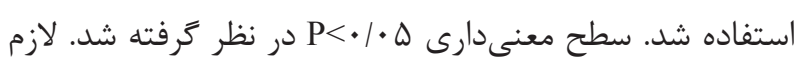
به ذكر است كه تحليل مطلع نبود.

\section{يافتهها}

در اين مطالعه فراوانى جنس در كروههاى آزمون و كنترل

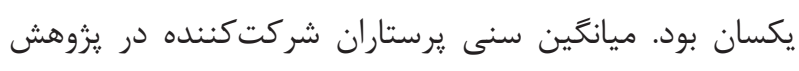

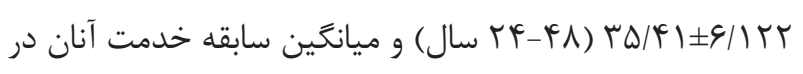

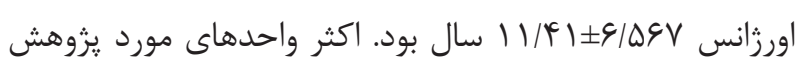

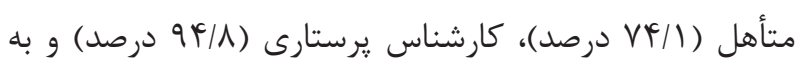

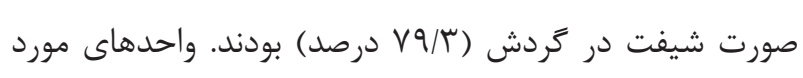

كنترل مداخلهاى توسط يروهشكر صورت نيذيرفت و فقط يك آن

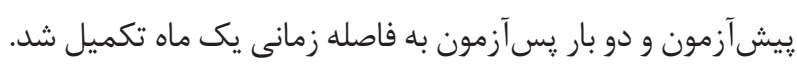

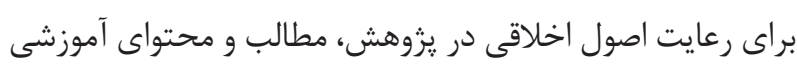

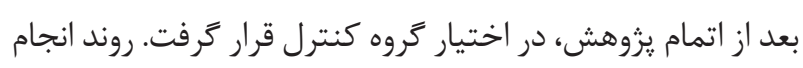
مطالعه در نمودار شماره يك نمايش داده شده است.

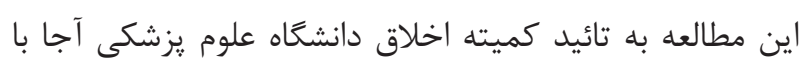

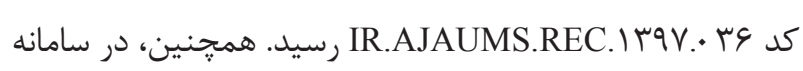
كارآزمايى بالينى ايران (Iranian Registry of Clinical Trials)

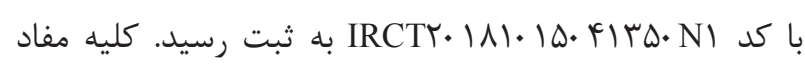
مطرح در بيانيه هلسينكى (Helsinki) در اين يروهش رعايت

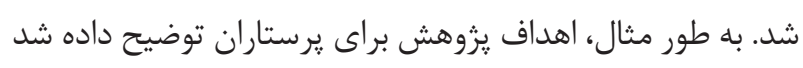

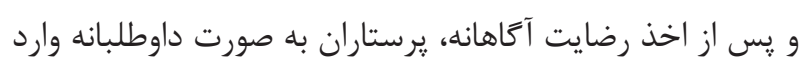

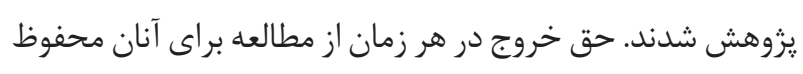
بود. تمام اطلاعات جمع آورى شده محرمانه بود و فقط در در اخد اختيار

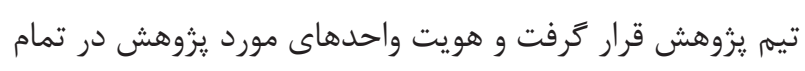
مراحل يزوهش محرمانه باقى ماند. در طول انجام يزوهش هيج

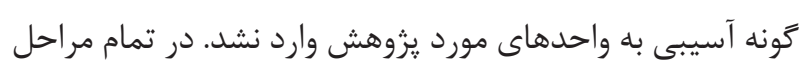
يروهش رعايت صداقت و امانتدارى در جمع آورى دادها و ارائه

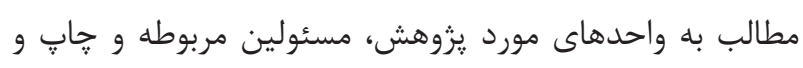

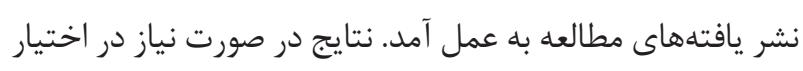

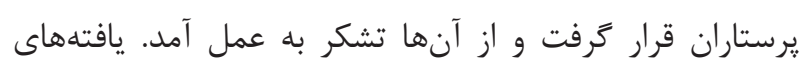

جدول ا - ميانگَين و انحراف معيار سن و سابقه خدمت (سال) يرستاران در سه كروه سخنرانى، بالينى و كنترل

\begin{tabular}{|c|c|c|c|c|c|c|c|c|c|}
\hline \multirow{2}{*}{ 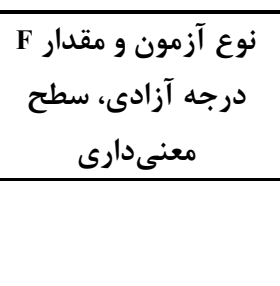 } & \multicolumn{2}{|r|}{ كل } & \multicolumn{2}{|c|}{ كروه كنترل } & \multicolumn{2}{|c|}{ تروه بالينى } & \multicolumn{2}{|c|}{ كروه سخنرانى } & \multirow{2}{*}{ متغير } \\
\hline & تعداد & $\begin{array}{l}\text { انحراف معيانگين } \\
\text { انيار }\end{array}$ & تعداد & $\begin{array}{l}\text { انحراف معيانگين } \\
\text { انيار }\end{array}$ & تعداد & $\begin{array}{l}\text { انحراف معيانگين } \\
\text { انيار }\end{array}$ & تعداد & $\begin{array}{c}\text { انحراف معيانگين } \\
\text { انحرار }\end{array}$ & \\
\hline 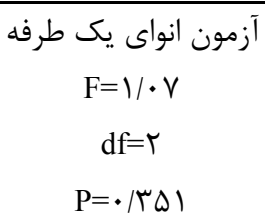 & $\Delta \wedge$ & $F / \mid r \pm r \Delta / \Psi^{\epsilon}$ & $r \cdot$ & $F / \cdot ৭ \pm r \varepsilon / V \Delta$ & 19 & $\Lambda / r \Lambda \pm r \Delta / \Delta r$ & 19 & 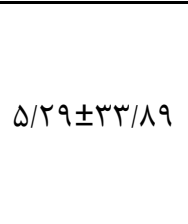 & سن \\
\hline 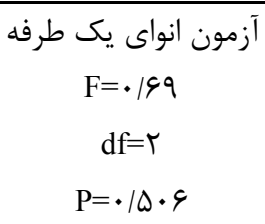 & $\Delta \Lambda$ & $\varepsilon / \Delta \pm|| / c \mid$ & $r \cdot$ & $F / q 1 \pm 1 \cdot / r$. & 19 & $q /|\Delta \pm| r / 9 \Lambda$ & 19 & $F / q 1 \pm 11 / 4 r$ & خابقه \\
\hline
\end{tabular}




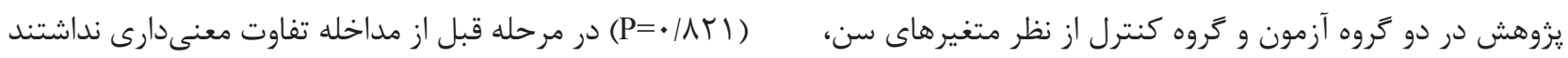

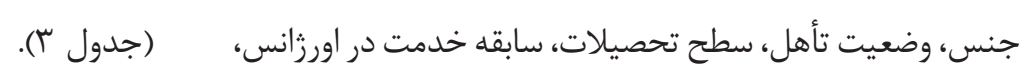

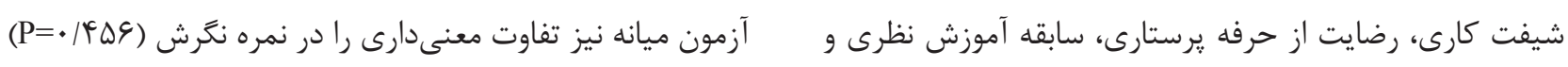

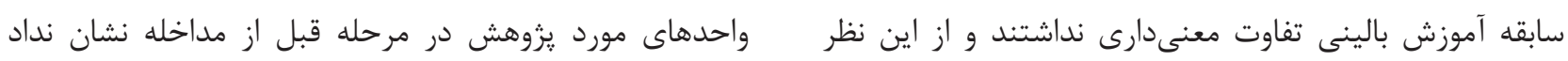

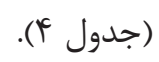

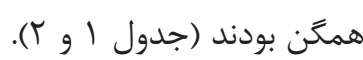

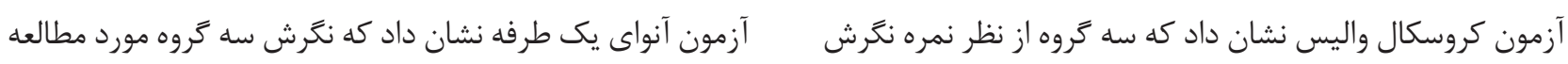

جدول r- توزيع فراوانى مطلق و نسبى بر ستاران در تروههاى سخنرانى، بالينى و كنترل بر حسب مشخصات فردى

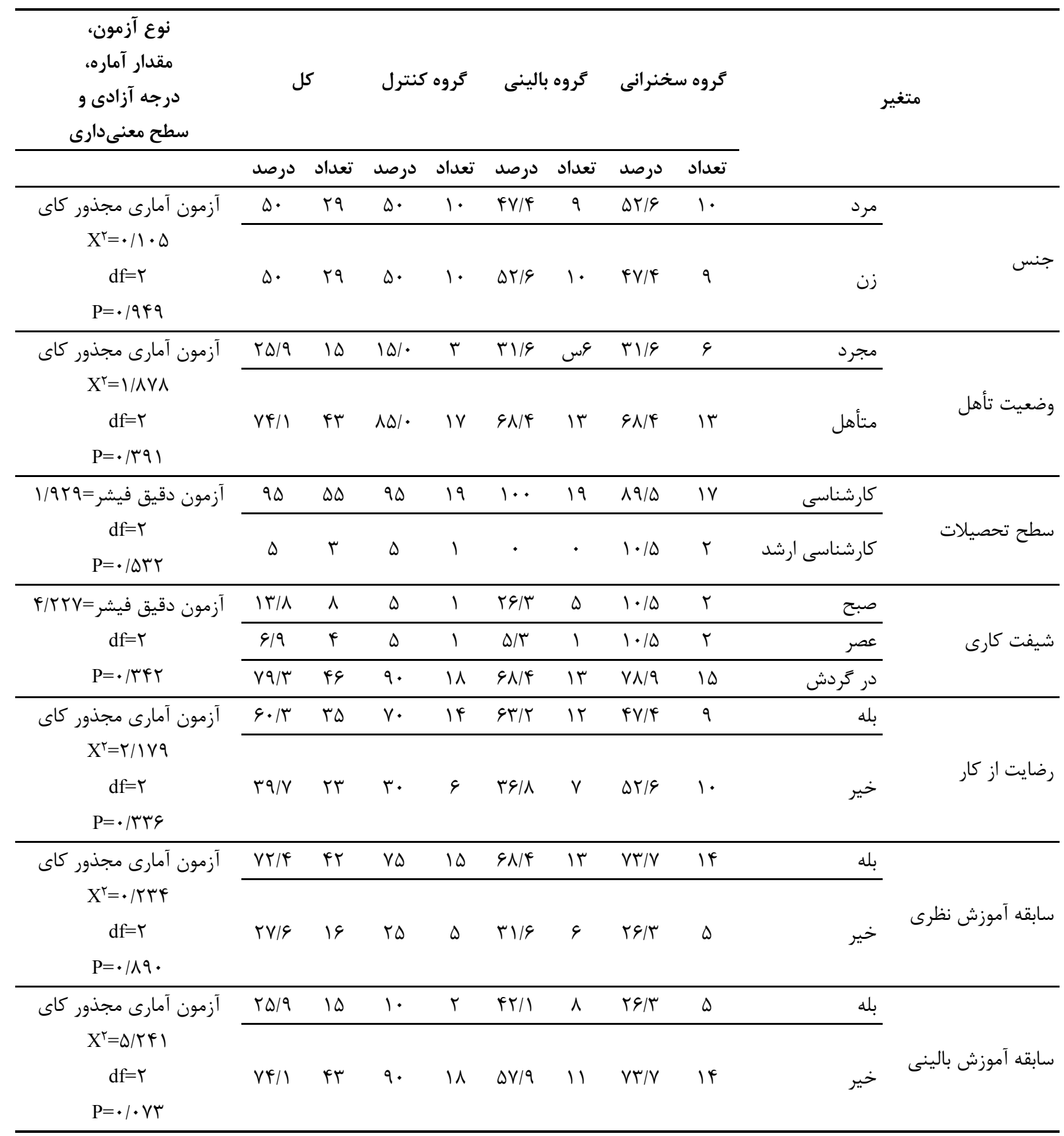




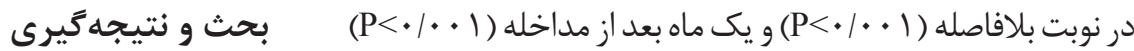
تفاوت معنى دارى داشتند. به طورى كه ميانگين نمره گروه بالينى اين مطالعه با هدف مقايسه تأثير آموزش به روش سخنرانى

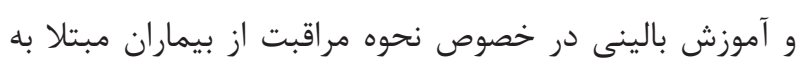
بالاتر از دو گروه ديخر بود (جدول ه). آزمون تعقيبى آنواى يك طرفه (يست هاك) نشان داد كه نگرش آنزين صدرى بر نخرش يرستاران بخش اورزانس انجام شد. يافتهها

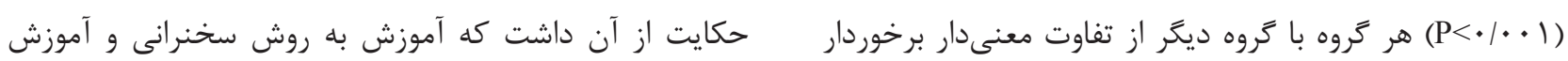
بالينى منجر به ارتقاى نكرش يرستاران اورزانس مىشود كه با

هستند (جدول ع).

جدول ץ- مقايسه نمره نكَرش يرستاران در خصوص نحوه مراقبت از بيماران آنزين صدرى قبل از مداخله در سه كروه سخنرانى، بالينى و كنترل نوع آزمون،

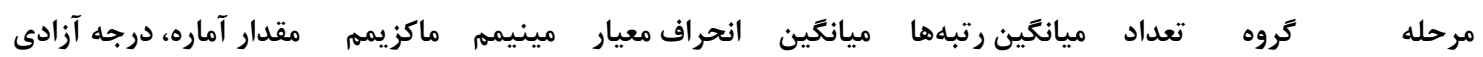
و سطح معنى

\begin{tabular}{|c|c|c|c|c|c|c|c|c|c|}
\hline آزمون كروسكال واليس & 10 & $1 \cdot$ & $1 / T \& \wedge$ & $11 / 90$ & TI/FT & 19 & سخنرانى & \multirow{4}{*}{ قبل از مداخله } & \multirow{4}{*}{ 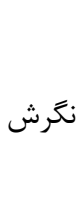 } \\
\hline$X r=\cdot / \mu q \Delta$ & If & 9 & I/TKY & س/911 & rN/GG & 19 & بالينى & & \\
\hline$d f=r$ & سו & $1 \cdot$ &.$/ 94$. & $11 / 9$. & rN/FA & $r \cdot$ & كنترل & & \\
\hline $\mathrm{P}=\cdot|\lambda T|$ & 10 & 9 & I/11Y & $11 / V T$ & - & $\Delta \Lambda$ & كل & & \\
\hline
\end{tabular}

جدول F - مقايسه نمرات نغرش يرستاران در مرحله قبل از مداخله در سه تروه سخنرانى، بالينى و كنترل بر اساس آزمون ميانه

\begin{tabular}{|c|c|c|c|c|c|c|}
\hline درجه آزادى و سطح معنى آزمون، مقدار آماره، & بيشتر از ميانه & كمتر يا مساوى ميانه & تعداد & & مرحله & \\
\hline 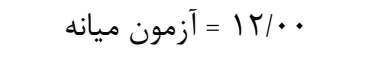 & 4 & 11 & 19 & روش سخنرانى & \multirow{3}{*}{ قبل از مداخله } & \\
\hline & r & 10 & 19 & روش بالينى & & نخرش \\
\hline $\mathrm{P}=\cdot / \mathcal{L} \Delta \varphi$ & r & IV & $r$. & روش كنترل & & \\
\hline
\end{tabular}

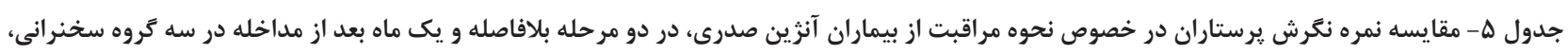
بالينى و كنترل

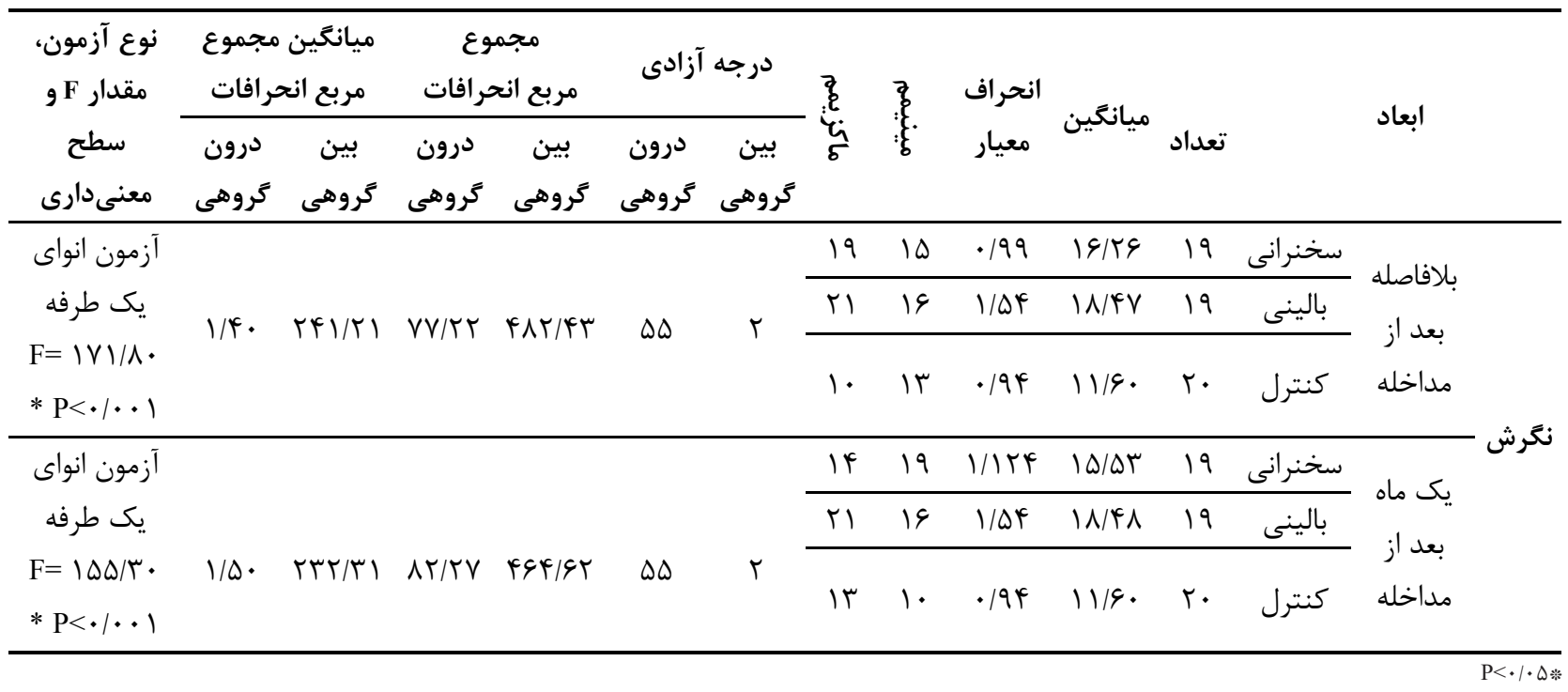


جدول و- مقايسه سطح نكَرش يرستاران در دو نوبت بلافاصله و يك ماه بعد از مداخله به تفكيك تروهها

\begin{tabular}{|c|c|c|c|c|c|}
\hline $\begin{array}{c}\text { آزمون تعقيبى يست هاك (Post-hoc) } \\
\text { سطح معنى دارى }\end{array}$ & اختلاف ميانگينها & وهما & & مرحله & \\
\hline$* \mathrm{P}<\cdot 1 \cdot \cdots 1$ & $-Y / T / 1$ & بالينى & \multirow{2}{*}{ سخنرانى } & \multirow{6}{*}{ بلافاصله بعد از مداخله } & \multirow{12}{*}{ 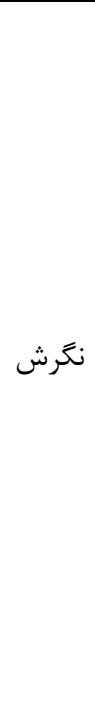 } \\
\hline$* \mathrm{P}<\bullet / \bullet 1$ & 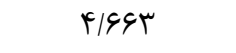 & كنترل & & & \\
\hline$* \mathrm{P}<\bullet / \cdot \bullet 1$ & $r / r) I$ & سخنرانى & \multirow{2}{*}{ بالينى } & & \\
\hline$* \mathrm{P}<\bullet / \cdots 1$ & s/AVt & كنترل & & & \\
\hline$* \mathrm{P}<\bullet \cdot \cdots 1$ & $-r / 99 \mu$ & سخنرانى & \multirow{2}{*}{ كنترل } & & \\
\hline$* \mathrm{P}<\cdot 1 \cdots 1$ & $-q \mid \wedge V F$ & بالينى & & & \\
\hline$* \mathrm{P}<\cdot / \cdots 1$ & $-r / 9 F V$ & بالينى & \multirow{2}{*}{ سخنرانى } & \multirow{6}{*}{ يكى ماه بعد از مداخله } & \\
\hline$* \mathrm{P}<\cdot 1 \cdots 1$ & r/qrg & كنترل & & & \\
\hline$* \mathrm{P}<\cdot 1 \cdots 1$ & T/qFV & سخنرانى & \multirow{2}{*}{ بالينى } & & \\
\hline$* \mathrm{P}<\cdot / \cdots 1$ & gIAVF & كنترل & & & \\
\hline$* \mathrm{P}<\bullet / \cdots 1$ & -r/9TG & سخنرانى & \multirow{2}{*}{ كنترل } & & \\
\hline$* \mathrm{P}<\cdot 1 \cdots 1$ & $-9 / \Lambda V F$ & بالينى & & & \\
\hline
\end{tabular}

شده است (19). يكى از محدوديتهاى اين يزوهش، حجم يايين نمونه و محدود إنه بودن نمونه يروهش به يرستاران بخش اورزانس بود، بنابراين نياز

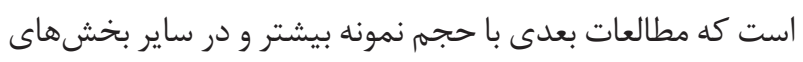

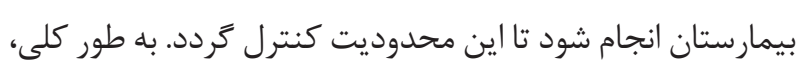

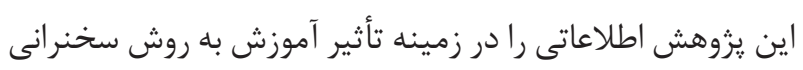
و آموزش به روش بالينى بر نكرش يرستاران در زمينه مراقبت

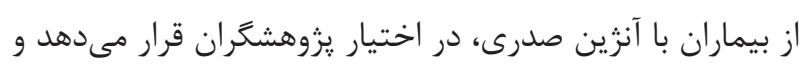
نتايج حاصل از آن مىتواند در حيطههاى مختلف مديريتى، بالينى، آنى آموزشى و يزوهشى قابل استفاده و استناد باشد و كام مؤثرى در جهت ارتقاى كيفيت مراقبت از بيماران آنزين صدرى و پيشخيرى از ايجاد عوارض در اين بيماران باشد. همجنين، اين مطالعه نشان

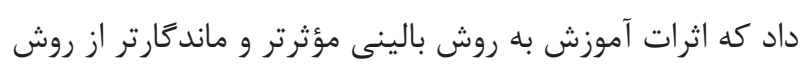
سخنرانى مىباشد. لذا، مديران، برنامهريزان و مسئولين آموزشى بهى مانى

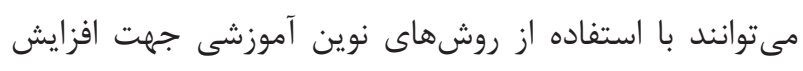
تغيير نخرش يرستاران در زمينه ارائه مهارتهاى بهـتر مؤثر باشند.

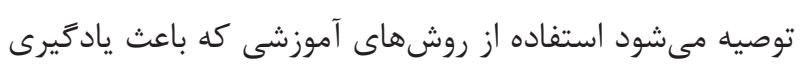

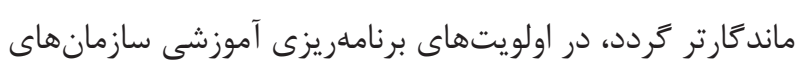
آموزشى و درمانى قرار خيرد.
ساير مطالعات همخوانى دارد. به طور مثال، با مطالعات رضايى

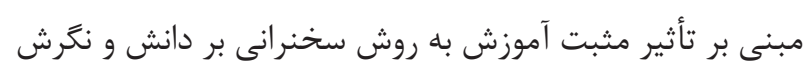
يرستاران (Y))، جفايى دلويى مبنى بر تأثير مثبت آموزش و يادَيرى بين حرفهاى در بهبود دانش، نخرش و مهارت حرفههاى سلامت (Y))، و مطالعه عشوندى مبنى بر تأثير مثبت كار كاههاى آموزشى بر آحاهى، نخرش و عملكرد يرستاران در زمينه كنترل درد (TV) همخوانى دارد. در مطالعه اديبى نيز گزارش شد كه نحرش يرستاران از طريق يك برنامه آموزشى مدون بين حرفهاى

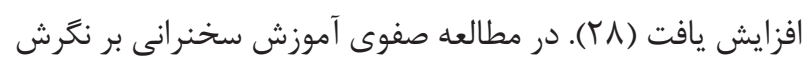
يرستاران نسبت به ماهيت بيمارى پاركينسون تأثير مثبت داشت

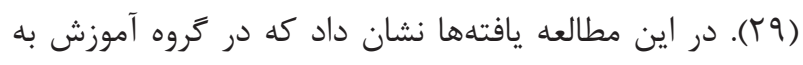
روش سخنرانى، نمرات نخرش در يك ماه بعد از مداخله نسبت به نمرات در مرحله بلافاصله بعد از مداخله، اندكى كاهش يافته بود كه مىتواند به علت فراموشى مطالب باشد، در حالى كه نمرات نخرش در گروه بالينى در مرحله بلافاصله و يك ماه بعد از مداخله

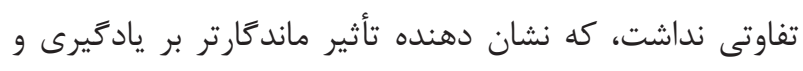

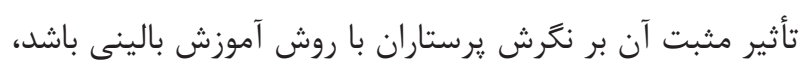

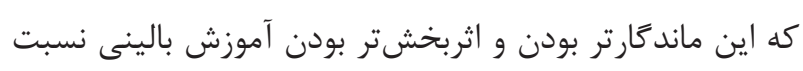
به آموزش به روش سخنرانى در مطالعه بلوردى نيز نشان داده 


$$
\begin{aligned}
& \text { علوم يزشكى آجا به ثبت رسيد و بودجه اين طرح توسط اين }
\end{aligned}
$$

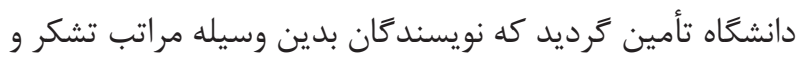

$$
\begin{aligned}
& \text { قدردانى خود را اعلام مى دارند. }
\end{aligned}
$$

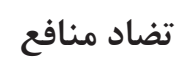

$$
\begin{aligned}
& \text { نويسندًان اعلام مىدارند كه هيجَّونه تضاد منافعى در اين } \\
& \text { يزوهش وجود نداشته است. }
\end{aligned}
$$

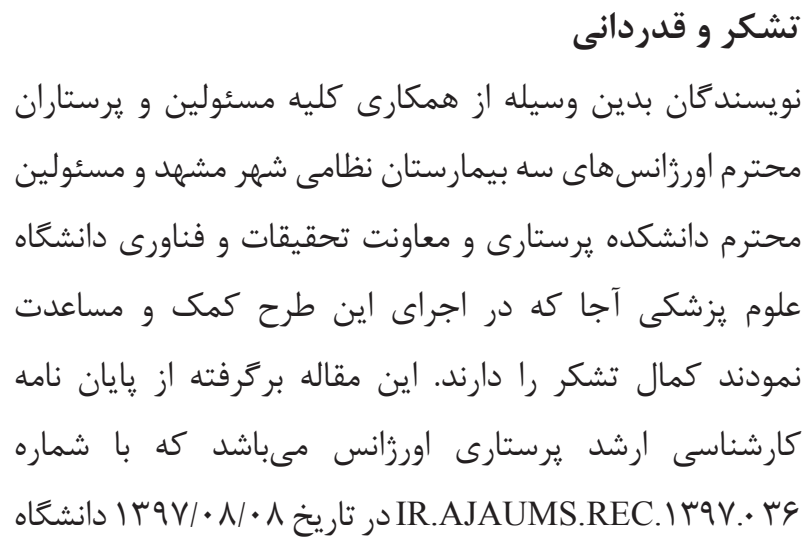

11- Bahador H, Feizi A, Nabizadeh M. A study on the midwifery students perception of the children, s care course by using TeamBased learning in coparison with conventional learning. J Urmian Nurs Midwifery Fac. 2015;13(6): 525-34.

12- Ruesseler M, Kalozoumi-Paizi F, Schill A, Knobe M, Byhahn C, Müller MP, et al. Impact of peer feedback on the performance of lecturers in emergency medicine: A prospective observational study. Scandi J of trau, Resuscitation and Emergency Medicine. 2014; 22(1): 71-8.

13- Jafarimanesh H, Zand S, Ranjbaran M, Varvani Farahani P, Sadrkia Gh. Comparing the effectiveness of SMS and lectures on the job training for nurses. Iran J Med Educ. 2016; 15(73): 577-88.

14- Ahmadi S, Zand S, Nikravan-Mofrad M, Rafiei F. Student satisfaction on getting feedback in clinical teaching. J Med Educ Dev. 2015; 10(3): 208-18.

15- Aliafsari Momghani E, Zamanzadeh V. Nursing clinical education challenges. J Med Educ Dev. 2017; 10(25): 68-81.

16- Kim HW, Kim DH, Kim YH, Lee EJ, Kang SY, Kim Y. Clinical nurses' awareness and caring experiences for patients with cervical cancer: A qualitative study. J Plos One. 2019; 14(5): 1-13.

17- Baskaran ND, Haron H, Valappil M. Demographics of healthcare professionals' knowledge and attitude toward deceased organ donation: Survey of critical care areas in a tertiary hospital. Med J Malaysia. 2019; 74(2) :109-15.

18- Abbaszadeh A, Sabeghi H, Heidary A, borhani F. Assessment of the effect of continuing education program on nurses knowledge, attitude and performance about documentation. J Mashhad Univ Med Sci. 2013; 2(2): 75-84.

19- Bolordi E, Reihani H, Pishbin E, Sanei A, Ebrahimi M. Comparison of educational effectivness between lecture and demonstration based methods on emergency medical services providers of Mashhad city in dealing with patient suspected of having acute coronary syndrome. J Mashhad Univ Med Sci. 2014; 5(57): 711-8.

20- Jafari M. Comparison of lecture and blender teaching methods on learning and satisfaction of medical students in biochemistry course. Iran J Med Educ. 2012; 12(7): 488-97.

21- Mokhtari Nouri J, Khademolhosseini M, Ebadi A, Moradi E. 
Effectiveness of lecture method on nurses learning levels in nursing education in nuclear accidents. Quart J Nurs Manage. 2012; 1(2): 27-36.

22- Asgari P, Mahmoudi M, Bahramnezhad F, Rafiei F, KhajehGoodari M. Comparison of the effect of three methods of education (inquiry-based, bedside education and routine approach to clinical education) on critical care nursing students clinical learning. J Med Educ Dev. 2016; 13(2): 133-41.

23- Smeltzer S BB, Hinkle J, Cheever K. Brunner \& sudarths Textbook of Medicai-Surgical Nursing. 14th, editor: Woltres kluwerhealth; 2017. 151-61 p.

24- Black J, Hawks J, Keene A Textbook of Medicai-Surgical Nursing. 8TH, editor: Elsevier Health Sciences; 2009. 102-12.

25- Hooseinrezaee H, Nouhi E, Taher Harikandee S. The effect of education on trauma critical care nurses attitudes towards and knowledge and practices from the viewpoint of their about application of physical restraint. J Nurs Educ. 2015; 1(11): 31-8

26- Jafaei Dalooei R, Karimi Moonaghi H, Yamani N, Irajpoor A.R, Saadatyar F. Intreprofessional education: the strategy to improve health care. Rec Med Educ. 2015; 1(7): 54-63.

27- Oshvandi Kh, Fallahinia Gh, Naghdi S, Moghimbeygi A, Karkhanei B. Effect of pain management training on knowledge attitude and pain relief methode of recovery nueses. J Nurs Educ. 2017; 6(4): 11-19.

28- Adibi P, Shahriari M, Doosti Irani M. Development of a curriculum for endoscopy nurse education in Iran. J Nurs Educ. 2016; 5(1): $38-43$.

29- Safavi M, Mahmoodi M, KalantarZadeh M. The effect of Nursing roles on the nurses knowledge and attitude toward nursing care of the patients with parkinson. J Res Dev Nurs Midwifery. 2013; 9(2): 27-35. 